\title{
Hyaluronic Acid and Wound Healing
}

\author{
Manuela G. Neuman ${ }^{1,2}$, Radu M. Nanau ${ }^{1}$, Loida Oruña-Sanchez ${ }^{3}$, Gabriel Coto ${ }^{4}$ \\ ${ }^{1}$ In Vitro Drug Safety \& Biotechnology, Toronto, Canada; ${ }^{2}$ Departments of Clinical Pharmacology \& Toxicology, \\ University of Toronto, Toronto, Canada; ${ }^{3}$ Natural Products Laboratory, Havana, Cuba; ${ }^{4}$ Department of Chemistry, Latino- \\ Americana Faculty of Medicine, Havana, Cuba.
}

Received, December 10, 2015; Revised, January 21, 2015; Accepted, January 26, 2015; Published, January 26, 2015.

\begin{abstract}
Background. We developed an experimental model of ethanol-induced dermatotoxicity and hepatocytoxicity using normal human keratinocytes and normal human hepatocytes that preserve inducible cytochrome p450 activities. The original work was described in several articles. The objective of this study was to determine whether hyaluronic acid attenuates skin necrosis, and to further clarify its uses in wound repair in humans, animal models and in vitro studies. Methods. We performed a systematic review of the literature using the terms "hyaluronic acid" and "wound healing". PubMed was searched for studies published during the period 2010-2014. Results. Hyaluronic acid is used in tissue regeneration alone or in combination with herbal or Western medicine. Scaffolds made up of hyaluronic acid were used to embed basic fibroblast growth factor. Conclusion. Hyaluronic acid extracts are safe and efficacious products to be used in skin repair.
\end{abstract}

This article is open to POST-PUBLICATION REVIEW. Registered readers (see "For Readers") may comment by clicking on ABSTRACT on the issue's contents page.

\section{INTRODUCTION}

Hyaluronic acid (HA) is a polysaccharide that belongs to the glycosaminoglycan family and consists of a basic unit of two sugars, glucuronic acid and N-acetyl-glucosamine. HA usually exists as a high molecular mass in the synovial fluid that surrounds joints, cartilage, and tissues of the eye and skin. Previously, our group was able to reduce alcohol-induced fibrogenesis in vitro in human normal hepatocytes (1) and to induce in vitro healing of human epithelial cells (2) using a preparation of HA obtained from human umbilical cord excision. The present work reviews in depth some of the mechanisms of tissue damage and repair in which HA plays an important role.

\section{TISSUE REGENERATION}

Recent studies using HA for tissue regeneration are discussed in Table 1. HA has recently been used in several in vitro studies (2-5). Our group has used HA jellies at concentrations of $2 \%, 4 \%$ and $8 \%$ that were formulated at the Placentary Histotherapy Center in Cuba from residual umbilical cords of human placentas obtained according to the National
Recollection Program. We showed that HA 2\% and $4 \%$ has a protective dose-dependent effect on skin cells exposed to ethanol. HA protected against ethanol-induced cytotoxicity by a mechanism that involves the prevention of apoptosis, and this is mediated by decreased inflammation. Cells exposed to the same amount of ethanol in the presence of HA $8 \%$ were not protected against toxicity. We believe this to be the result of an inability of this highly viscous gel to penetrate into the cells (2). In a separate study, Wu et al. (5) show that high molecular weight (HMW)-HA (1525 kDa) has superior cytoprotective effects compared to low molecular weight (LMW)-HA (127 kDa). HMWHA $0.3 \%$ facilitates cell migration and wound healing (5). HMW-HA also promotes wound healing and cell survival in a rat heart ischemiareperfusion model, while LMW-HA has no protective effects (4). Another recent in vitro study showed that amniotic fluid is associated with reepithelialisation, mediated by the presence of HA (3).

Corresponding Author: Manuela G. Neuman, M.Sc., Ph.D., FCACC; Department of Pharmacology and Toxicology, University of Toronto, In Vitro Drug Safety and Biotechnology; Banting Institute, 100 College Street, Lab 217, Toronto, Ontario, Canada, Email: manuela.neuman@utoronto.ca 
HA was further used in animal models (6-13). HA was used for its wound healing potential in two full-thickness surgical wound models. HA facilitated re-epithelialization, led to the formation of soft tissue with good elasticity, and increased microvascular density $(6,7)$. HA also showed promising results for connective tissue repair in terms of tendon and cartilage repair in two rabbit models $(8,9)$. Bone repair is further shown in rat and rabbit models $(10,11)$. Zanchetta et al. (11) found that histological and overall appearance of the healing bone were superior in untreated hole made in the left side of the parietal bone compared to HA-treated hole made in the right side. Better results obtained in the control site could be partly explained by the transport of the treatment components in blood, thereby spreading them evenly and suggesting systemic activity (11).

The use of chitosan-hyaluronan/silk fibroin cardiac patches led to cardiac repair in a rat model of myocardial infarction. Blood vessel-like structures were widely distributed in myocardial infarction regions of the left ventricle in the treatment group, yet were absent under the control condition. This further led to higher secretion of paracrine factors in myocardial infarction regions of the left ventricle in the treatment group compared to control (12). In another rat model, artificial tears containing $\mathrm{HA}$ and high potassium ion concentration promoted corneal epithelial wound healing in a mechanical scraping model but not in an alkali burn model (13).

HA was used in humans in several studies (1421). The skin re- epithelialization potential of Avena rhealba extract ${ }^{\circledR}$ and $\mathrm{HA}$ was shown in a small sample of volunteers in which skin lesions were produced with erbium-YAG laser (14). Different gel formulations of HA were used in burn patients $(15,16)$, and for the treatment of persistent ulcers (17-19). Four cases of upper limb deep wounds treated with HA, bacterial fermented sodium hyaluronate salt $(0.2 \% \mathrm{w} / \mathrm{w})$, and bacterial collagenase obtained from non-pathogenic Vibrio alginolyticus are described in a case series. Aside from wound healing, this treatment led to satisfactory aesthetic results, and optimal recovery of the affected limb functionality (22).

In humans, platelet rich plasma and HA were used to treat postoperative wound dehiscence and tendon exposure after surgery in patients with Morton's neuroma, an entrapment neuropathy of the plantar digital nerve (21). Elsewhere, the application of HA-containing gels in early wound healing after scaling and root planting was tested in individuals with chronic periodontitis. HA led to significantly higher reduction in probing depth, as well as the number of pockets with probing depth $\geq 5 \mathrm{~mm}$, compared to scaling and root planting alone (20).

Table 1: Tissue Regeneration Studies

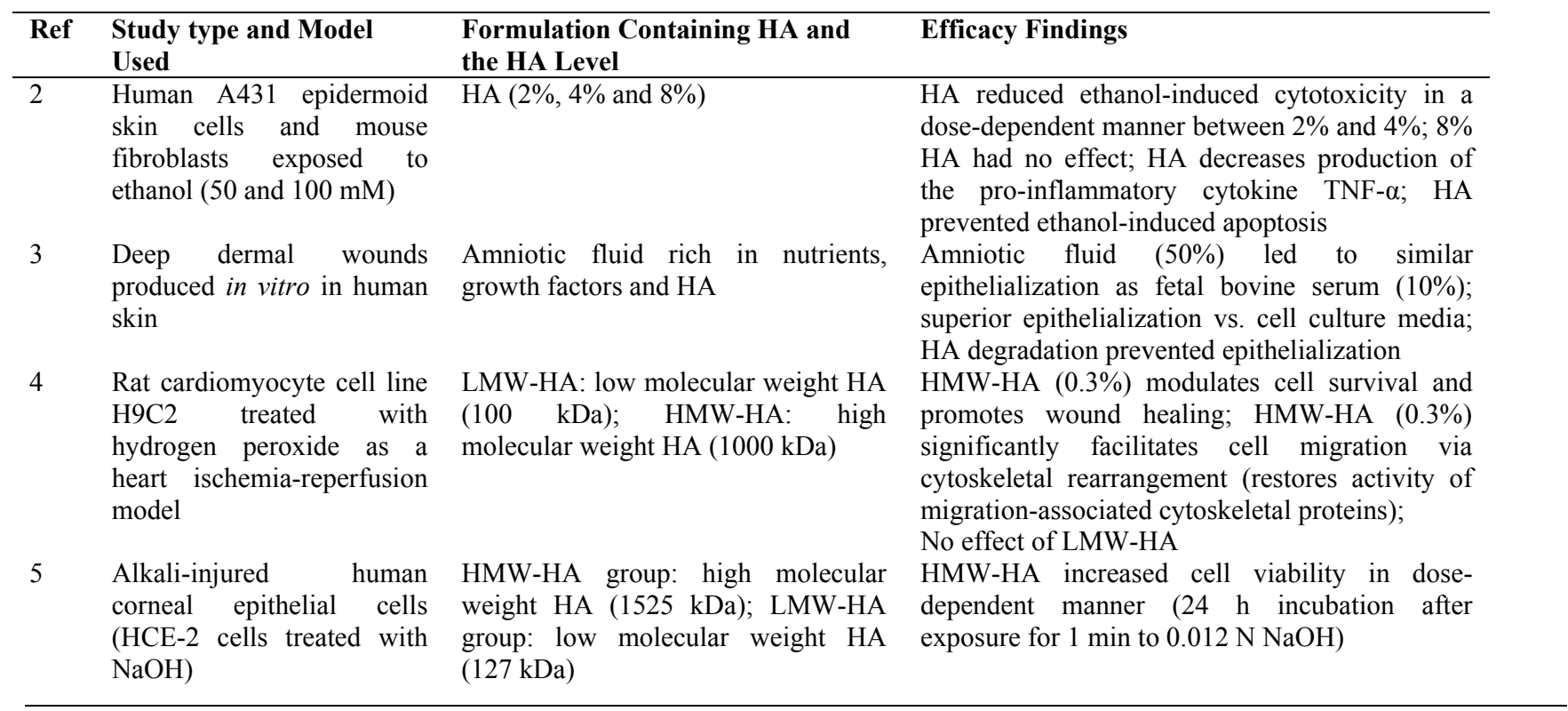


Table 1: Tissue Regeneration Studies (Cont'd)

$\begin{array}{ll}\text { Ref } & \begin{array}{l}\text { Study type and Model } \\ \text { Used }\end{array} \\ 6 & \begin{array}{l}\text { Full-thickness pieces of } \\ \text { rabbit skin }\end{array}\end{array}$
the HA Level

rabbit skin

Rabbit superficial digital flexor tendon rupture; full thickness tendon transection and surgical repair

9 Rabbit knee articular defect (induced articular cartilage defect)

10 Anterior wall of the maxillary sinus removed in rabbit

$4 \mathrm{~mm}$ circumferential wound on both the nasal and the sinus side

$7 \quad$ Full-thickness surgical wound in rats

Full-thickness skin defect in diabetic mice

11 Rat critical size defect model (hole made in parietal bone)

12 Myocardial infarction induced by cryoinjury in rat

13 Epithelial defects on the corneas in rat: mechanical scraping and alkali burns

14 RTC $(\mathrm{n}=21)$; skin deepidermised by Er-YAG laser in healthy volunteers

Cohort $\quad(n=60)$; partial thickness burns (average $3 \%$ total body surface area); (control): untreated
Formulation Containing HA and

\section{Efficacy Findings}

HA1 group: porcine acellular dermal matrix + HA $(0.3 \mathrm{~mL}$ exogenous HA, about $\left.0.17 \mathrm{mg} / \mathrm{cm}^{2}\right)+$ thin skin autograft; HA2 group: porcine acellular dermal matrix + HA ( $0.6 \mathrm{~mL}$ exogenous HA, about $\left.0.34 \mathrm{mg} / \mathrm{cm}^{2}\right)+$ thin skin autograft; PADM group: porcine acellular dermal matrix + thin skin autograft; TS group: thin skin autograft; NS group: normal skin

$\mathrm{NaH}$ group: exogenous sodium hyaluronate injected subcutaneously over the lesion; Control group: saline injection

Treatment: bilateral knee arthrotomies, chondral

defects, microfracture + intraarticular HA; Control: saline

Rapid-gelling HA hydrogel or preformed HA hydrogel filled randomly into the right or left sinus; Blank control or Merogel control into the other sinus

EGF dressing: HMW-HA spongy sheet (upper layer) + arginine, magnesium ascorbyl phosphate and EGF (lower layer); Control: epidermal growth factor-free dressing

Right hole (treatment): HA, chondroitin 6 sulphate, dermatan sulphate and $2.5 \%$ saline solution; Left hole

Treatment group: chitosan-HA/silk fibroin cardiac patches implanted in left ventricle; Control group: no patches

Artificial tears containing HA $(0.3 \%$ or $0.15 \%)+$ high-K ion concentration; PBS

Group A: Avena rhealba $\operatorname{extract}{ }^{\circledR}+$ HA; Group B: reference product (panthenol and madecassoside); Group C: reference product (resveratrol-copper); Group D untreated control

Zinc-HA gel
Skin grafts grew well in all groups; HA1 and HA2: soft with good elasticity; PADM: quite hard with poor elasticity; TS: thin and susceptible to tearing; NS: best elasticity among all the groups; Collagen I and III content on day 28: higher in HA1 and HA2 than rest; higher in HA1 than HA2; Microvascular density at day 14: higher in HA1 and HA2 than other groups; higher in HA2 than HA1

Time-dependent decrease in the diameter of the injured tendon: superior in $\mathrm{NaH}$ vs. control;

Treatment was effective in restoring morphological and biomechanical properties of lacerated superficial digital flexor tendon rupture

Higher potential for healing in the experimental group, with thicker and more organized repair tissue in treatment vs. control

HA preserved neo-ostium opening (prevented ostial stenosis); Degree of lymphocyte or plasmacyte infiltration similar between groups; Preformed HA hydrogel led to lower acute inflammation and heterophile infiltration; Rapidgelling HA reduced fibrosis and osteogenesis; HA hydrogel promoted wound healing Substantially facilitate epithelialization, granulation tissue formation and angiogenesis in rat; EGF dressing superior to EGF-free dressing; Improved wound condition and decreased wound size, and facilitated epithelialization, granulation tissue formation and angiogenesis in mouse; EGF dressing superior to EGF-free dressing

Substantial periosteal macroscopic neoangiogenesis at both sites

Reduced the dilation of the inner diameter of left ventricle in treatment $(p<0.05)$; Increased wall thickness of left ventricle in treatment $(p<0.05)$; Improved the fractional shortening of left ventricle of hearts $(\mathrm{p}<0.05)$

Mechanical scraping model: smaller areas of fluorescein staining in the eyes in HA + high-K artificial tears vs. PBS by $36 \mathrm{~h}$; Alkali burn model: no significant effect of $\mathrm{HA}+$ high-K artificial tears vs. PBS by $36 \mathrm{~h}$

Laser wound completely healed after 9 days in groups A and B, 12 days in group C, and 16 days in group $\mathrm{D}$; Healing generally slow between days 1 and 6, faster thereafter; Safety profiles of treatments were favorable and comparable

On average, wound size reduced by $50 \%$ by day 5; Full epithelialization in $93.3 \%$ of sample by day 21 ; Resolution of pain in $91.7 \%$ of sample by day $10 ;$ No infections 
Table 1: Tissue Regeneration Studies (Cont'd)

\begin{tabular}{|c|c|c|c|}
\hline ef & $\begin{array}{l}\text { Study type and Model } \\
\text { Used }\end{array}$ & $\begin{array}{l}\text { Formulation Containing } \mathrm{HA} \text { and } \\
\text { the HA Level }\end{array}$ & Efficacy Findings \\
\hline 8 & $\begin{array}{l}\text { Cohort } \quad(n=40) ; \text { persistent } \\
\text { ulcers }\end{array}$ & $\begin{array}{l}\text { Bionect Start }{ }^{\circledR} \text { ointment (collagenase } \\
\text { product containing HA) }\end{array}$ & $\begin{array}{l}\text { Relevant reduction of the ulcer size after } 5 \text { weeks } \\
\text { in } 80.0 \% \text { of sample, and mild or no improvement } \\
\text { in } 20.0 \% \text { of sample; Decrease in pain in } 50.0 \% \\
\text { of sample, no pain in } 40.0 \% \text { of sample, and no } \\
\text { change in pain intensity in } 10.0 \% \text { of sample; } \\
\text { Bacterial infection in wound exudates in } 23.3 \% \\
\text { of sample }\end{array}$ \\
\hline 6 & $\begin{array}{l}\text { Cohort }(\mathrm{n}=30) \text {; second- } \\
\text { degree skin burns in the } \\
\text { phase of } \\
\text { epithelialization }\end{array}$ & $\begin{array}{l}\text { Topical ozonated oil vs. topical HA } \\
\text { gel }\end{array}$ & $\begin{array}{l}\text { Both agents equally effective in reducing } \\
\text { symptoms related to skin burns such as } \\
\text { erythema, tension, itching and burning sensation; } \\
\text { Both agents led to self-reported improved } \\
\text { general appearance of skin lesions; Ozonated oil } \\
\text { prevented post-lesion hyperpigmentation better } \\
\text { than HA }\end{array}$ \\
\hline 17 & $\begin{array}{l}\text { RTC ( }=89) ; \text { venous leg } \\
\text { ulcers }\end{array}$ & $\begin{array}{l}\text { Topical HA (gauze pad) vs. neutral } \\
\text { vehicle control }\end{array}$ & $\begin{array}{l}\text { Percentage of wound size reduction at day } 45: 73 \\
\pm 4.6 \% \text { in HA vs. } 46 \pm 9.6 \% \text { in control } \\
(\mathrm{p}=0.011) \text {; Number of healed ulcers: } 31.1 \% \text { in } \\
\text { HA vs. } 9.3 \% \text { in control at day } 45 \text { and } 37.8 \% \text { vs. } \\
16.3 \% \text { at day } 60 \text {; Pain intensity based on visual } \\
\text { analogue scale lower in HA vs. control; One case } \\
\text { of heart attack in HA group and one death not } \\
\text { related to therapy }\end{array}$ \\
\hline 19 & $\begin{array}{l}\text { RTC } \quad(n=124) ; \quad \text { pressure } \\
\text { ulcers }\end{array}$ & $\begin{array}{l}\text { Control: no treatment; } 1 \times \text { PRGF: } \\
\text { one dose of platelet-rich growth } \\
\text { factor }(n=34) ; 2 \times \text { PRGF: two doses } \\
\text { of platelet-rich growth factor }(n=25) ; \\
2 \times \text { PRGF }+ \text { HA: two doses of } \\
\text { platelet-rich growth factor }+ \text { HA } \\
(n=40)\end{array}$ & $\begin{array}{l}\text { Reduction in ulcer area in all groups at day } 36 \\
\text { (mean reduction } 48 \% \text { vs. baseline); higher in all } \\
\text { treatment groups vs. control; greatest in } 2 \times \\
\text { PRGF + HA (mean } 80.4 \% \text { vs. baseline); } \\
\text { Complete wound healing: } 32.0 \% \text { in } 2 \times \text { PRGF } \\
(\mathrm{p}<0.002) \text { and in } 37.5 \% 2 \times \text { PRGF }+ \text { HA } \\
(p<0.004) \text {; No infections by day } 36\end{array}$ \\
\hline 20 & $\begin{array}{l}\text { RTC } \quad(n=34) \\
\text { periodontitis }\end{array}$ & $\begin{array}{l}\text { Test group: scaling and root planting } \\
+ \text { HA; Control group: scaling and } \\
\text { root planting alone }\end{array}$ & $\begin{array}{l}\text { Probing depth and number of pockets with } \\
\text { probing depth } \geq 5 \text { mm reduced in both groups; } \\
\text { superior in test vs. control at months } 3 \text { and } 6 \text {; } \\
\text { Reduction in Treponema denticola and } \\
\text { Campylobacter rectus counts; superior in test vs. } \\
\text { control }\end{array}$ \\
\hline 21 & $\begin{array}{l}\text { Case series }(\mathrm{n}=5) \text {; wound } \\
\text { dehiscence and tendon } \\
\text { exposure after Morton's } \\
\text { neuroma surgery excision }\end{array}$ & $\begin{array}{l}\text { Platelet rich plasma }+ \text { 3D } \\
\text { polymerised } \\
\text { biological dressings } \\
\begin{array}{l}\text { growth factors } \\
\text { growedicated }\end{array} \\
\end{array}$ & $\begin{array}{l}\text { Complete wound healing at day } 30 \text {; Walking } \\
\text { regained after an average } 2 \text { weeks; No adverse } \\
\text { events }\end{array}$ \\
\hline \multicolumn{4}{|c|}{$\begin{array}{l}\text { Ref: reference number; EGF: epidermal growth factor; HA: hyaluronic acid; HMW: high molecular weight; K: potassium; } \\
\text { CMW: low molecular weight; NaH: sodium hyaluronate; NaOH: sodium hydroxide; NS: normal skin; PADM: porcine acellular } \\
\text { dermal matrix; PBS: phosphate buffered saline; PRGF: platelet-rich growth factor; Ref: reference; RTC: randomized clinical } \\
\text { rial; TNF: tumor necrosis factor; TS: thin skin. }\end{array}$} \\
\hline
\end{tabular}

\section{SCAFFOLD FOR WOUND HEALING}

Table 2 describes studies in which HA was used as a component of scaffolds for wound healing. A number of animal studies using wound models assessed the usefulness of HA-based scaffolds (2330). These scaffolds, made up of various biological components, promote dermis regeneration and wound healing. In one case, dermal/epidermal cell fractions entrapped directly within the hydrogel accelerated wound healing. Elsewhere, the scaffold was used to embed basic fibroblast growth factor (23-26).

An injectable hydrogel provided an adhesion barrier in a rat model following midline abdominal incision, and facilitated wound healing (27). An HA-based spongy sheet embedded with epidermal growth factor aided wound healing in a rat model with excised portion of the peritoneum (28). Bone formation was achieved in two calvaria defect 
models using HA-based scaffolding. In one study, these scaffolds were loaded with growth and differentiation factor 5, which aided new bone formation with increased bone mineral density (29, 30). In a retrospective study, an HA sheet was used as scaffold with or without autologous cultured dermal fibroblasts after the removal of basal cell carcinoma on the face (31). The use of autologous skin grafting on an HA scaffold in patients undergoing surgical scar removal facilitates better integration of the graft into the surrounding tissues, with dermis regeneration (32).

\section{CONCLUSION}

HA is commonly used as a therapeutic in a wide range of applications, including osteoarthritis, ophthalmic surgery, cosmetic application and tissue engineering. It may be injected intradermally or it may be used topically. HA extracts are safe and efficacious products to be used in skin repair.

\section{ACKNOWLEDGMENTS}

In Vitro Drug Safety and Biotechnology, Toronto, Canada supported the work. All authors have read the journal's policy on conflicts of interest and have none to declare. Also, all authors have read the journal's policy on authorship and there are no conflicts of interest.

Table 2. Scaffold for Wound Healing Studies

\begin{tabular}{|c|c|c|}
\hline Ref. & Model Used & Description of HA Scaffold \\
\hline 23 & $\begin{array}{l}\text { Rat; Full thickness skin } \\
\text { wounds }\end{array}$ & $\begin{array}{l}\text { Scaffolds constructed of silk } \\
\text { fibroin, chondroitin sulfate and HA }\end{array}$ \\
\hline 24 & $\begin{array}{l}\text { Rat; Full thickness skin } \\
\text { wounds }\end{array}$ & $\begin{array}{l}\text { Treatment: porous scaffold made up } \\
\text { of collagen, HA and gelatin; } \\
\text { Control: no treatment }\end{array}$ \\
\hline 27 & $\begin{array}{l}\text { Rat; Midline abdominal } \\
\text { incision }\end{array}$ & $\begin{array}{l}\text { Control: no adhesion barrier; } \\
\text { Interceed group: Interceed } \\
\text { absorbable adhesion barrier; HA } \\
\text { group: HA alone; mcALG group: } \\
\text { mildly cross-linked alginate; } \\
\text { HA/mcALG: HA embedded in } \\
\text { mildly cross-linked alginate }\end{array}$ \\
\hline 29 & $\begin{array}{l}\text { Rat; Critical-size calvaria } \\
\text { defects }\end{array}$ & $\begin{array}{l}\text { HA: } 1.0 \% \text { HA; HA + ACS: } 1.0 \% \\
\text { HA + absorbable collagen sponge; } \\
\text { ACS: absorbable collagen sponge; } \\
\text { Control: no treatment }\end{array}$ \\
\hline 25 & $\begin{array}{l}\text { Mouse; Full thickness skin } \\
\text { wounds }\end{array}$ & $\begin{array}{l}\text { Treatment: } \\
\text { dermal/epidermal cell fractions } \\
\text { entrapped directly within a gellan } \\
\text { gum/HA spongy-like hydrogel; } \\
\text { Control: no treatment }\end{array}$ \\
\hline 26 & $\begin{array}{l}\text { Rabbit; Full thickness skin } \\
\text { wounds }\end{array}$ & $\begin{array}{l}\text { Xenogeneic de-cellularized scaffold } \\
\text { from pig peritoneum and } \mathrm{HA}+ \\
\text { basic fibroblast growth factor }(1 \text { or } \\
3 \mu \mathrm{g} / \mathrm{mL})\end{array}$ \\
\hline
\end{tabular}

Efficacy Findings

Scaffold containing silk fibroin, chondroitin sulfate and HA led to superior dermis regeneration (smaller wound area), with improved angiogenesis and collagen deposition compared to scaffold lacking collagen; Expression of growth factors was initially superior in the fibroin, chondroitin sulfate and HA group, and decreased with progression of wound healing

Scaffold ameliorates wound healing, decreases neutrophyils infiltrates and thickens newly generated skin; Small wound area in treatment vs. control, with faster healing

mcALG and HA/mcALG shielded the injury site, thus preventing peritoneal tissue adhesion and facilitated wound healing

HA + ACS showed superior bone filling potential vs. control $(p<0.005)$ and ACS $(p=0.017)$; HA similar to other treatments

Accelerated wound closure rate, re-epithelialization and neovascularization in treatment vs. control

Faster would healing rates and superior dermis regeneration with scaffold, regardless of basic fibroblast growth factor concentration 
Table 2. Scaffold for Wound Healing Studies (Cont'd)

\begin{tabular}{|c|c|c|c|}
\hline Ref. & Model Used & Description of HA Scaffold & Efficacy Findings \\
\hline 30 & $\begin{array}{l}\text { Rabbit; Critical-size calvaria } \\
\text { defects }\end{array}$ & $\begin{array}{l}\text { Treatment: HA hydrogels loaded } \\
\text { with growth and differentiation } \\
\text { factor } 5(0,10,100 \text { or } 1000 \mathrm{ng} / \mathrm{mL} \\
\text { GDF-5);Control: no treatment }\end{array}$ & $\begin{array}{l}\text { More significant new bone formation, larger bone } \\
\text { formation area, larger bone volume and bone mineral } \\
\text { density in treatment conditions with larger GDF-5 } \\
\text { concentration }\end{array}$ \\
\hline 28 & $\begin{array}{l}\text { Rat (in vitro); Excised portion } \\
\text { of peritoneum: spongy sheet } \\
\text { placed on the peritoneal defect } \\
\text { in rats }\end{array}$ & $\begin{array}{l}\text { Anti-adhesive spongy sheet } \\
\text { composed of HA and collagen }+ \\
\text { epidermal growth factor } \\
\text { Wound surface model (spongy } \\
\text { sheet on top of fibroblast- } \\
\text { incorporating collagen gel sheet) } \\
\text { Inter-tissue model (spongy sheet } \\
\text { between two fibroblast- } \\
\text { incorporating collagen gel sheets) }\end{array}$ & $\begin{array}{l}\text { Spongy sheet stimulates fibroblasts to release an } \\
\text { increased amount of vascular endothelial growth factor } \\
\text { and hepatocyte growth factor; Spongy sheet facilitated } \\
\text { wound healing and preventing surgically excised tissue } \\
\text { from adhering to surrounding tissue }\end{array}$ \\
\hline 31 & $\begin{array}{l}\text { Retrospective study }(\mathrm{n}=29) \\
\text { Patients with removal of basal } \\
\text { cell carcinoma from face }\end{array}$ & $\begin{array}{l}\text { Tissue-engineered } \\
\text { composed of autologous cultured } \\
\text { dermal fibroblasts seeded on HA } \\
\text { sheet }\end{array}$ & $\begin{array}{l}\text { Re-epithelization occurred progressively from the } \\
\text { periphery to the center of the wound }\end{array}$ \\
\hline
\end{tabular}

Ref: reference; ACS: absorbable collagen sponge; HA: hyaluronic acid; HMW: high molecular weight; GDF: growth and differentiation factor; LMW: low molecular weight; mcALG: mildly cross-linked alginate

\section{ACKNOLEDGMENT}

In Vitro Drug Safety and Biotechnology, Toronto, Canada supported the work.

\section{REFERENCES}

1. Neuman MG, Nanau RM, Oruña L, Coto G. In vitro anti-inflammatory effects of hyaluronic acid in ethanol-induced damage in skin cells. J Pharm Pharm Sci, 2011; 14:425-437.

2. Neuman MG, Oruña L, Coto G, Lago G, Nanau R, Vincent M. Hyaluronic acid signals for repair in ethanol-induced apoptosis in skin cells in vitro. Clin Biochem, 2010; 43:822-826.

3. Nyman E, Huss F, Nyman T, Junker J, Kratz G. Hyaluronic acid, an important factor in the wound healing properties of amniotic fluid: in vitro studies of re-epithelialisation in human skin wounds. J Plast Surg Hand Surg, 2013; 47:89-92.

4. Law CH, Li JM, Chou HC, Chen YH, Chan HL. Hyaluronic acid-dependent protection in $\mathrm{H} 9 \mathrm{C} 2$ cardiomyocytes: a cell model of heart ischemiareperfusion injury and treatment. Toxicology, 2013; 303:54-71.

5. Wu CL, Chou HC, Li JM, Chen YW, Chen JH, Chen YH, Chan HL. Hyaluronic acid-dependent protection against alkali-burned human corneal cells. Electrophoresis, 2013; 34:388-396.
6. Zhao JY, Chai JK, Song HF, Zhang J, Xu $\mathrm{MH}$, Liang YD. Influence of hyaluronic acid on wound healing using composite porcine acellular dermal matrix grafts and autologous skin in rabbits. Int Wound J, 2013; 10:562-572.

7. Shimizu N, Ishida D, Yamamoto A, Kuroyanagi M, Kuroyanagi Y. Development of a functional wound dressing composed of hyaluronic acid spongy sheet containing bioactive components: evaluation of wound healing potential in animal tests. J Biomater Sci Polym Ed, 2014; 25:12781291.

8. Oryan A, Moshiri A, Meimandi Parizi AH, Raayat Jahromi A. Repeated administration of exogenous Sodium-hyaluronate improved tendon healing in an in vivo transection model. J Tissue Viability, 2012; 21:88-102.

9. Tuncay I, Erkocak OF, Acar MA, Toy H. The effect of hyaluronan combined with microfracture on the treatment of chondral defects: an experimental study in a rabbit model. Eur $\mathbf{J}$ Orthop Surg Traumatol, 2013; 23:753-758. 
10. Chen Q, Sun G, Wang Y, Zhong W, Shu XZ. The evaluation of two new hyaluronan hydrogels as nasal dressing in the rabbit maxillary sinus. Am J Rhinol Allergy, 2012; 26:152-156.

11. Zanchetta P, Lagarde N, Uguen A, Marcorelles P. Mixture of hyaluronic acid, chondroitin 6 sulphate and dermatan sulphate used to completely regenerate bone in rat critical size defect model. J Craniomaxillofac Surg, 2012; 40:783-787.

12. Chi NH, Yang MC, Chung TW, Chou NK, Wang SS. Cardiac repair using chitosan-hyaluronan/silk fibroin patches in a rat heart model with myocardial infarction. Carbohydr Polym, 2013; 92:591-597.

13. Ho WT, Chiang TH, Chang SW, Chen YH, Hu FR, Wang IJ. Enhanced corneal wound healing with hyaluronic acid and high-potassium artificial tears. Clin Exp Optom, 2013; 96:536-541.

14. Sabadotto M, Theunis J, Black D, Mengeaud $\mathrm{V}$, Schmitt AM. In vivo assessment of the effect of a cream containing Avena Rhealba extract ${ }^{\circledR}$ andhyaluronic acid on the restoration of the skin barrier in de-epidermised skin produced with an erbium-YAG laser. Eur J Dermatol, 2014. In press. doi:10.1684/ejd.2014.2406.

15. Juhász I, Zoltán P, Erdei I. Treatment of partial thickness burns with Zn-hyaluronan: lessons of a clinical pilot study. Ann Burns Fire Disasters, 2012; 25:82-85.

16. Campanati A, De Blasio S, Giuliano A, Ganzetti G, Giuliodori K, Pecora T, Consales V, Minnetti I, Offidani A. Topical ozonated oil versus hyaluronic gel for the treatment of partial- to full-thickness second-degree burns: A prospective, comparative, single-blind, non-randomised, controlled clinical trial. Burns, 2013; 39:1178-1183.

17. Humbert P, Mikosinki J, Benchikhi H, Allaert FA. Efficacy and safety of a gauze pad containing hyaluronic acid in treatment of leg ulcers of venous or mixed origin: a double-blind, randomised, controlled trial. Int Wound J, 2013; 10:159-166.

18. Onesti MG, Fioramonti P, Carella S, Fino P, Sorvillo V, Scuderi N. A new association between hyaluronic acid and collagenase in wound repair: an open study. Eur Rev Med Pharmacol Sci, 2013; 17:210-216.

19. Ramos-Torrecillas J, García-Martínez O, LunaBertos ED, Ocaña-Peinado FM, Ruiz C. Effectiveness of Platelet-Rich Plasma and Hyaluronic Acid for the Treatment and Care of Pressure Ulcers. Biol Res Nurs, 2014. In press. doi: 10.1177/1099800414535840.

20. Eick S, Renatus A, Heinicke M, Pfister W, Stratul SI, Jentsch H. Hyaluronic Acid as an adjunct after scaling and root planing: a prospective randomized clinical trial. J Periodontol, 2013; 84:941-949.

21. De Angelis B, Lucarini L, Orlandi F, Agovino A, Migner A, Cervelli V, Izzo V, Curcio C. Regenerative surgery of the complications with Morton's neuroma surgery: use of platelet rich plasma and hyaluronic acid. Int Wound J, 2013; 10:372-376.

22. Onesti MG, Fino P, Ponzo I, Ruggieri M, Scuderi N. Non-surgical treatment of deep wounds triggered by harmful physical and chemical agents: a successful combined use of collagenase and hyaluronic acid. Int Wound J, 2014. In press. doi: 10.1111/iwj.12215.

23. Yan S, Zhang Q, Wang J, Liu Y, Lu S, Li M, Kaplan DL. Silk fibroin/chondroitin sulfate/hyaluronic acid ternary scaffolds for dermal tissue reconstruction. Acta Biomater, 2013; 9:6771-6782.

24. Wang HM, Chou YT, Wen ZH, Wang CZ, Chen $\mathrm{CH}$, Ho ML. Novel biodegradable porous scaffold applied to skin regeneration. PLoS One, 2013; 8:e56330.

25. Cerqueira MT, da Silva LP, Santos TC, Pirraco RP, Correlo VM, Marques AP, Reis RL. Human skin cell fractions fail to self-organize within a gellan gum/hyaluronic acid matrix but positively influence early wound healing. Tissue Eng Part A, 2014; 20:1369-1378.

26. Wu Z, Fan L, Xu B, Lin Y, Zhang P, Wei X. Use of decellularized scaffolds combined with hyaluronic acid and bFGF for skin tissue engineering. Tissue Eng Part A, 2014. In press. doi: 10.1089/ten.TEA.2013.0260.

27. Na SY, Oh SH, Song KS, Lee JH. Hyaluronic acid/mildly crosslinked alginate hydrogel as an injectable tissue adhesion barrier. J Mater Sci Mater Med, 2012; 23:2303-2313.

28. Kuroyanagi M, Yamamoto A, Shimizu N, Toi A, Inomata T, Takeda A, Kuroyanagi Y. Development of anti-adhesive spongy sheet composed of hyaluronic acid and collagen containing epidermal growth factor. J Biomater Sci Polym Ed, 2014; 25:1253-265.

29. de Brito Bezerra B, Mendes Brazão MA, de Campos ML, Casati MZ, Sallum EA, Sallum AW. Association of hyaluronic acid with a collagen scaffold may improve bone healing in critical-size bone defects. Clin Oral Implants Res, 2012; 23:938942.

30. Bae MS, Ohe JY, Lee JB, Heo DN, Byun W, Bae H, Kwon YD, Kwon IK. Photo-cured hyaluronic acidbased hydrogels containing growth and differentiation factor 5 (GDF-5) for bone tissue regeneration. Bone, 2014; 59:189-198.

31. Han SK, Kim SY, Choi RJ, Jeong SH, Kim WK. Comparison of tissue-engineered and artificial 
dermis grafts after removal of basal cell carcinoma on face--a pilot study. Dermatol Surg, 2014; 40:460467.

32. Faga A, Nicoletti G, Brenta F, Scevola S, Abatangelo G, Brun P. Hyaluronic acid threedimensional scaffold for surgical revision of retracting scars: a human experimental study. Int Wound J, 2013; 10:329-335.
33. King, SR, Hickerson, WL, Proctor, KG. Beneficial actions of exogenous hyaluronic acid on wound healing. Surgery, 1991; 109:76-79.

34. Chen, WY, Abatangelo, G. Functions of Hyaluronan in Wound Repair. Wound Repair Regen 1999; 7:7984. 